\title{
Ethical practices of small and medium-sized enterprises in developing countries: Literature analysis
}

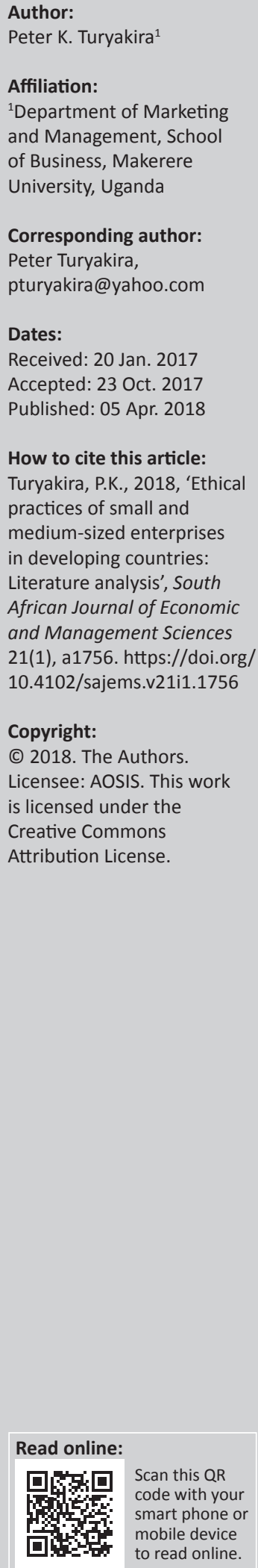

Background: There is increasing pressure on business organisations to behave ethically, in addition to running their operations in the most economical, efficient and effective manner possible to increase performance. Customers have also become increasingly mindful of the reputation of the businesses they patronise. Small and medium-sized enterprises (SMEs) have become the worst affected since they lack the funds, strategic information and relevant alliances to implement ethical practices.

Aim: This article aims at evaluating the aspects of business ethics, significance of business ethics to SMEs, ethical dilemmas and challenges of SMEs, particularly in developing countries, and suggests strategies to address ethical dilemmas and challenges.

Methods: The background literature review on ethical practices in SMEs in the context of developing countries was conducted on several journal articles. Peer-reviewed articles in recent journals were analysed to identify the aspects of business ethics, significance of business ethics to SMEs, ethical dilemmas and challenges of SMEs and the proposed strategies to address ethical dilemmas and challenges thereof.

Results and conclusion: It is clear that business enterprises can no longer afford to disregard business ethics. There are continuous business failures as a result of unethical practices, especially those associated with employees and top executives. This article has added to the body of existing literature on ethical practices of SMEs in developing countries. As such, SME owners and managers can use the findings of this article to design ethical policy frameworks and guidelines to improve their reputations and competitiveness.

\section{Introduction}

There is currently increasing pressure on business organisations to be ethical, in addition to running their operations in the most economical, efficient and effective manner possible to increase performance (Khomba \& Vermaak 2012). Due to continually changing competitive environments, businesses must also find new ways of meeting competition other than the traditional ways of offering better products, or lower prices (McMurrian \& Matulich 2006). It is important to note that modern businesses employ people with diverse backgrounds in terms of nationality, culture, religion, age, education and socioeconomic status. Each of these persons comes into the workplace with different values, goals and perceptions of acceptable behaviour. This diverse background creates ethical challenges for individuals as well as managers (Abiodun \& Oyeniyi 2014). Businesses have realised that ethical misconduct can be very costly not only for the organisation but also to society as a whole (Abiodun \& Oyeniyi 2014). Furthermore, today's customers have become increasingly mindful of the reputation of the businesses they patronise. Consequently, small and medium-sized enterprises (SMEs) have become the worst affected since they lack the funds, strategic information and relevant alliances (Ononogbo, Joel \& Edeja 2016) to implement ethical practices.

Regardless of their size, business enterprises can no longer afford to disregard business ethics (Sraboni \& Sharmistha 2011). SMEs, and not small, medium and micro enterprises (SMMEs), are chosen for this study because they are more formal compared to SMMEs. It is notable that SMEs, which have been playing a leading role in the business domain in the last few decades, have remained outside the floodlights of review regarding the issue of business ethics (Werner \& Spence 2004). There are also continuous business failures as a result of unethical practices especially those associated with employees (Sraboni \& Sharmistha 2011). This in turn has adversely affected SMEs' reputations (Ononogbo et al. 2016). With the expanding role of SMEs globally, an ethical approach towards business is imperative for them (Sraboni \& Sharmistha 2011). Hence, business organisations and managers need to behave ethically and protect their 
own business interests (Abiodun \& Oyeniyi 2014) if they are to survive and remain competitive.

There is also increasing awareness of ethics, leading societies to disapprove of businesses that are found to be ethically ill (Ahmad, Amran \& Halim 2012). However, the study of the role and function of ethics in business organisations has unfortunately focused primarily on larger enterprises, even though SMEs exert a strong influence on the economies of all countries, particularly in the fastchanging and increasingly competitive global market (Naidoo, Perumal \& Moodley 2009). While many large companies have gained their reputation by applying ethical standards, SMEs in developed countries are progressively becoming more alert to the significance of trustworthy dealings with employees, clients, suppliers and society. However, SMEs in developing countries still require more understanding and awareness of the implication of business ethics and its benefits. They may be unable to recognise such gains due to lack of a long-term vision (Mahmood 2008). The unique opportunities and challenges that SMEs encounter often tempt them to diverge from ethical practices when interacting with their stakeholders, especially the employees (Sraboni \& Sharmistha 2011). Hence, the study of business ethics has become imperative in today's competitive business environment.

This article attempts to evaluate the aspects of business ethics, significance of business ethics to SMEs, ethical dilemmas and challenges of SMEs, particularly in developing countries, and to suggest strategies to address ethical dilemmas and challenges. This article focuses on SMEs in developing countries because of their role in economic growth and poverty reduction. SMEs also contribute to economic development by creating employment for the rural and urban population. In developing countries, SMEs employ more than $70 \%$ of the labour force (Mahmood 2008). For example, in Thailand, SMEs account for more than $90 \%$ of the total number of establishments, $65 \%$ of employment and $47 \%$ of manufacturing value added, while in Philippines, SMEs comprise 99\% of the total manufacturing establishments and contribute $45 \%$ of employment and $18 \%$ of value added in the manufacturing sector (Mahmood 2008). In Africa, SMEs account for more than $90 \%$ of businesses and contribute about $50 \%$ of gross national product (GDP) (Kamunge, Njeru \& Tirimba 2014). For instance, in Kenya, SMEs contribute $40 \%$ of the GDP, over $50 \%$ of new jobs and account for $80 \%$ of the workforce (Mwarari \& Ngugi 2013). In Uganda, SMEs constitute over $90 \%$ of businesses operating in the private sector; they contribute to $75 \%$ of GDP and employ approximately 2.5 million people (Hatega 2007; Uganda Ministry of Finance, Planning and Economic Development 2011). This article will inform SME stakeholders, especially SME owners and managers in developing countries, to create and promote an environment that nurtures and facilitates the SME sector and enables it to realise its true potential. The article will also add to a body of knowledge with regard to SME ethical practices in developing countries.

\section{Aspects of business ethics}

Ethics refers to a system of moral principles or rules of behaviour which involves doing the right thing in the right manner (Okafor 2011). According to Mujtaba (2005), ethics is the branch of philosophy that theoretically, rationally and reasonably determines right from wrong, good from bad, moral from immoral, and fair from unfair actions and behaviour. Behaving ethically implies doing what is morally right (Okafor 2011; Riley 2012). According to Abiodun and Oyeniyi (2014), ethics is based on broad principles of integrity, transparency, accountability, responsibility and fairness, and focuses on internal stakeholder issues such as product quality, customer satisfaction, employee wages and benefits, and local community and environmental responsibilities. Ethics is also viewed as the moral values and principles that guide action and behaviour (Emerson 2009). It is the discipline that deals with what is good and bad and with moral duty and obligations. Ethical rules of conduct generally attempt to provide guidelines of human behaviour that will preserve a society and its individual members. Bucholz (2003) views ethics as guiding values, principles and standards that help people determine how things ought to be done. Similarly, Spence and Van Heekeren (2005) regard ethics as a set of prescriptive rules, virtues, values and principles that inform and guide conduct. Hence, ethics means moral principles that govern the action of an individual or a group (Abiodun \& Oyeniyi 2014). Most scholars generally agree that ethics is a set of principles, rules, morals and values that inform and guide the conduct of individuals and groups in society or a business organisation.

Business ethics is basically the study of morality and standards of business conduct. According to Twomey and Jennings (2011), business ethics denotes the application of ethics to business practices. It is simply the application of general ethical rules to business behaviour (Hodgelts \& Luthans 2003). According to Elbert and Griffin (2003), business ethics refers to ethical or unethical behaviour by a manager or employee of an organisation and varies from person to person, from situation to situation, and from culture to culture. Velentzas and Broni (2010) view business ethics as the set of moral principles and values that take control over the behaviour of the organisation with reference to what is regarded as right and wrong. As such, business ethics can be seen as what is regarded as right and wrong or good and bad human behaviour in a business setting. Hence, what is regarded as right or wrong can obviously be influenced by various factors such as the type of staff and their cultural background, and will vary from business to business (Wiid, Cant \& Van Niekerk 2013). Business ethics involves how a business integrates core values such as honesty, trust, respect and fairness into its policies, practices and decision-making (Hellriegel et al. 2008). Rossouw (2004) asserts that business ethics is about identifying and implementing standards of conduct that will ensure that a business does not detrimentally affect the interests of its stakeholders. For businesses to be profitable today, they must conduct their activities in such a way that 
they can be seen as ethical. Therefore, ethics point towards the application of morality, while morality is derived from ethics (Borade 2012).

It should be noted that an individual's moral sense guides moral behaviour (Krebs 2011). This is in line with Borade (2012) who asserts that while business ethics signifies the abstract moral code accepted and obeyed by members of the business, morality is the judgements, values and guidelines of good conduct in the workplace. As such, morality is what guides people towards acceptable behaviour, with respect to basic values (Mujtaba 2005). According to Borade (2012), morality refers to an adopted code of conduct within an environment and a set of agreed-upon rules for what is right and wrong. On the other hand, Krebs (2011) asserts that morality is the equilibrium of individuals, which implies that interaction takes place according to a set of rules that balances the benefits and burdens of cooperation.

Ethical practices are the conscious compliance with the standard of morality that guides an individual and business to follow certain norms of conduct when dealing with people within and outside the organisation (Ononogbo et al. 2016). As such, unethical business practices usually reflect the values, attitudes, beliefs and behaviour patterns of the organisational culture. According to Abiodun and Oyeniyi (2014), business decisions and behaviour may be judged ethical or unethical, depending on whether the decisions and actions promote or threaten the values and standards of individuals and the societies in which a business operates. However, ethical standards are not static ideals but dynamic patterns of human conduct. Ethical standards, therefore, reflect the end product of a process of defining and clarifying the nature and content of human interaction.

When identifying the business's core values, it may help to think of some values as business values and others as ethical values, although the distinction can be insignificant, and business and ethical values are often interrelated. Some common values of SMEs are shown in Table 1 below. In SMEs, these values will inevitably be influenced by the personal and professional values and principles of the owners or managers.

\section{Significance of business ethics to small and medium-sized enterprises}

It is important to note that in the 21st century, power in the market has shifted from producers and sellers to buyers and consumers (Weinstein 2012). Where stakeholders have control over markets and can affect business performance, ethical practices are critical success factors when it comes to business (Twomey \& Jennings 2011). As such, business owners and employees must exercise good faith in the practices they engage in if they are to continuously make profits. Businesses that operate without regard for ethical values are likely to run into problems with the law, customers, employees and business partners. Consequently, business reputation will suffer and the loss of business from unethical
TABLE 1: Ethical and business values.

\begin{tabular}{ll}
\hline Ethical values & Business values \\
\hline Integrity & Customer service \\
Honesty & Quality \\
Openness & Innovation \\
Respect & Reliability \\
Fairness & Efficiency \\
Responsibility & Value for money \\
\hline
\end{tabular}

Source: Adapted from Business Ethics Briefing, 2010, Institute of business ethics, London, Charity no: 1084014, issue 6, viewed 06 January 2010, from http://www.ibe.org.uk

behaviour could be significant and difficult to erase. Customers value ethical businesses and once a business has lost trust by being unethical, customers will seek alternatives and much will be lost to competitors, or in the process of defending against lawsuits (Donovan 2013). However, SMEs must be especially cautious to balance the goals of profits with the values of individuals and society by practising good business ethics (Twomey \& Jennings 2011). Hence, businesses need good ethical values to survive.

Ethical and socially responsible practices benefit entrepreneurs financially in the long run. This means that behaviour associated with maintaining honesty and integrity, being trustworthy, engaging in fair commercial practices, taking responsibility and being accountable for one's own actions are very important for SMEs in the long run (Ahmad 2009). According to Goll and Rasheed (2004), in fast-changing and unpredictable environments, ethical and socially responsible behaviour helps businesses to gain support from different external stakeholder groups. Such behaviour provide them with some protection from the unpredictability they face. As such, a business's image and reputation may be influenced by the good practices it exhibits to its customers and to the general public (Jones 2000). The benefits of ethical practices enable competitive advantage to be attained as a business distinguishes itself from its competitors (Ahmad 2009). In fact, businesses with high ethical codes of conduct and a commitment to enhancing integrity are not only profitable but more likely to succeed in a commercially competitive world (Hasnah, Ishak \& Sobei 2015).

Although some managers consider ethics programmes in their organisations to be very expensive activities that are only societally rewarding (McMurrian \& Matulich 2006), businesses that are viewed as ethical by their key stakeholders (i.e. customers, employees, suppliers and public) do enjoy several competitive advantages such as higher levels of efficiency in operations, higher levels of commitment and loyalty from employees, higher levels of perceived product quality, higher levels of customer loyalty and retention, and better financial performance (Ferrell 2004). Hence, high standards of organisational ethics can contribute to profitability by reducing the cost of business transactions and building a foundation of trust with important stakeholders (McMurrian \& Matulich 2006).

Business activities require the maintenance of basic ethical standards, such as honesty, reliability and cooperation. Businesses cannot survive if their directors never tell the 
truth, if buyers and sellers never trust each other or if the employees refuse to provide support to each other and to customers (Branko, Drago \& Zoran 2015). Good ethics in terms of being fair, honest, responsible and upright helps to build credibility and trust for businesses. Customers and other stakeholders want to engage businesses and business owners whom they can fully trust with their happiness, needs and wants, their money and their safety, health and well-being (Donovan 2013). Therefore, SME owners must see business investment, growth and sales as stemming from a circle of trust (Twomey \& Jennings 2011). There is indeed a link between a business's commitment to values and its financial performance (Chun et al. 2011; Twomey \& Jennings 2011). While not conclusive, research (Webley \& More 2013) has shown that the relationship between good financial performance and other indicators of corporate responsibility is positive. Hence, businesses have something to gain financially from being ethical. After all, being ethical should naturally create a solid and better reputation that leads to recognition by stakeholders, especially customers who, in turn, increase their loyalty and are willing to purchase with more confidence and make referrals. As such, SMEs must develop their ethical presence and reputation in order to remain strong in the eyes of customers (Donovan 2013).

Furthermore, when a business has a good reputation, it benefits from a good name and its good deeds are noticed by the public. Having an ethical conscience and being ethically conscientious is the best approach to building a good reputation. This requires SMEs to be fair, honest, carry out decisions and operations with integrity and consideration, be trustworthy, and respond to stakeholders' needs for action and community engagement (Donovan 2013). Building a good reputation can pay off in the long run as the business becomes well-endorsed by business stakeholders and creates new customers. Hence, good reputation can build lifetime customer value as it leads to stronger customer relationships (Peppers \& Rogers 2004; Weinstein 2012). SMEs that ethically conduct their businesses are likely to have a positive effect on sales and profits, experience a lower incidence of staff turnover, as well as increased productivity, as employees prefer to work at an ethical organisation, easily attract potential employees wanting to work for the organisation, thereby reducing recruitment costs and helping the company get the right skills, and protect the business from a possible hostile takeover by attracting investors (Wiid et al. 2013). Hence, SMEs need to develop ethical policies and adhere to them in their day-to-day operations.

The lack of general ethics among SME owners affects the growth opportunities of business by negatively impacting customer loyalty, brand building and deterring investment partners (Kalyar, Rafi \& Kalyar 2013). This also creates a stereotype and perceptions of a general lack of credibility and reputation among SMEs, thereby affecting their ability to compete with larger businesses and to obtain funding for development. Hence, it is imperative for SMEs to appreciate the nature and importance of business ethics in order to develop strategies and solutions to effectively address existing challenges and minimise business failure, increase opportunities for growth, competitiveness and performance, and improve their general reputation in industry and community (Donovan 2013).

Indeed, the importance of business ethics cannot be overemphasised (Mahmood 2008). The advantages of adopting business ethics include:

- Investors use business practices and values as primary considerations in their decision-making.

- As customers are becoming increasingly aware of their rights, they value ethical practices. Hence, adopting ethics can help to build reputation of businesses.

- Promoting reputation can help in building customer loyalty and increase revenue.

- Attract a talented workforce and employees thus improving business performance and productivity of employees.

- Comply with regulations such as labour laws and environment.

- Collaboration with other firms both domestically and internationally.

According to Sraboni and Sharmistha (2011), a satisfied and motivated workforce is the primary step towards long-term success in business. Ethical practices towards the employees can warrant job satisfaction and enhanced motivation levels of employees, which eventually leads to better business profitability. Essentially, ethical hiring practices, the implementation of a rational performance appraisal system, a formal procedure for employee replacement, a proactive approach towards handling employee grievances, workplace safety and voluntary investments for employee welfare are all instrumental towards creating an ethical work climate. Furthermore, encouraging employees to participate in decision-making, attending to the training and development needs of employees, without discrimination, and presence of a formal code of ethics in the organisation are also ethical issues that motivate employees (Sraboni \& Sharmistha 2011).

\section{Ethical dilemmas and challenges of small and medium-sized enterprises}

The practice of providing benefits to someone in business or government to obtain an inappropriate market, workplace or economic advantage is widely judged as an unethical practice. This is due mainly to the evil effects of corruption, bribery and fraud. This practice is widespread in most developing countries especially African nations. In fact, it is so institutionalised in a number of Africa nations such as Nigeria and Somalia that it is the only effective way of doing business (Abiodun \& Oyeniyi 2014). In many cases, bribery in African nations transcends the level of being referred to as unethical to being a common practice (Unruh \& Arreola 2009). There is evidence to suggest that these vices of corruption, bribery and fraud hinder the creation of an acceptable legal system, encourage red tape and bureaucracy, 
thus eroding public confidence and trust, and blocking the development of the infrastructure on which business organisations depend (Unruh \& Arreola 2009). Relatedly, piracy and counterfeiting practices have become more prevalent in many developing countries. Piracy and counterfeiting adversely affect society and businesses (Abiodun \& Oyeniyi 2014).

Unethical behaviour has indeed become prevalent in businesses of all sizes today, and they pose significant risks to business organisations and their stakeholders (Wiid et al. 2013). SMEs are in a more vulnerable position today with regard to corruption, fraud and other unethical practices. This is attributed to the fact that they need to survive and as they tend to be small in size, they experience more difficulties. SMEs are especially vulnerable to the practice and consequences of unethical business behaviour (Medlin \& Green 2003) due to their size, limited finances and funding sources, their dependence on word-of-mouth strategies to market products, dependence on sometimes overpowering customers, difficulty in building a reputation and their tendency to take shortcuts when doing business. However, SMEs in the developing countries lack awareness and understanding of the importance of business ethics and its advantages. SMEs lack long-term vision and focus more on survival in the short term. Due to lack of financial resources to build a formal ethical culture, SMEs in some countries like Pakistan embrace unethical practices in order to remain afloat. For example, they seek unethical schemes to access low-quality goods at lower prices and evade taxation so that they have the upper hand over their competitors (Mahmood 2008; Tarus \& Nganga 2013). Others accept contracts at lower prices than they should because there are no rules governing their operation.

Furthermore, lack of information, credit, scale economies, quality and reputation make most SMEs very uncompetitive (Tarus \& Nganga 2013). On the other hand, SMEs are aware of the large scale of unethical practices taking place in large companies and government departments, which they see as standard or acceptable practice. Therefore, this may influence their behaviour and perceptions, and even make them more open to dishonest behaviour (Wiid et al. 2013). In some instances, SMEs see these unethical actions as necessary for survival. Their size ultimately limits their resources and capabilities to avoid corruption and fraud in the business sector. Consequently, many, particularly in developing countries accept corruption and fraud as normal, acceptable practices and utilise these as a means of getting something done quicker, even when they know that it is illegal and unethical (Rune 2011).

Developing entrepreneurial culture and ethical business environment are critical challenges for SMEs (Mahmood 2008). It should be noted that SMEs are primarily driven by the personal beliefs and values of their owners and also face significant resource pressure. This may lead SMEs towards more individualist ethical postures such as non-repayment of credit (Hopkins 2005). The common unethical practices in businesses include padding expense accounts, seeking reimbursement for questionable or non-existent business expenses, taking business property or materials for personal use, soliciting or offering kickbacks and price fixing (Ononogbo et al. 2016). This is in line with Botha (2012) who states that the most common ethical concerns about misconduct in the business environment include bribery, coercion or bullying, theft, discrimination, fraud, harassment, dishonesty, cover-ups and pornography. Similarly, Collins (2012) observes that the most common forms of ethical misconduct experienced by many businesses are abuse of a company's resources, abusive behaviour towards employees, lying to employees, Internet abuse, conflict of interest, discrimination, lying to stakeholders, employee benefit abuse, employee privacy violation and falsifying expenses. However, it should be noted that these actions of misconduct are not limited to large organisations, but equally apply to SMEs in all sectors. For instance, in a survey conducted by Collins of SME professionals, the major concerns identified regarding ethical behaviour were kickbacks paid to employees, honesty in contracts and internal communications, and the granting of pay raises. By nature of their limited size, SMEs may also be more prone to bullying from a large unethical customer or supplier (Collins 2012).

On the basis of the current economic climate and the realities faced by SMEs, moral concerns are widespread as there are various conflicting standards and interests due to rare resources, high uncertainty and risk, vague roles, and continuous competitive strain. The most challenging moral issue that businesses encounter is to decide between upholding normative business ethics and following their own selfishness for their own interest (Bryant 2009). It is obvious that employees and managers are ill equipped to cope with ethical challenges due to a number of reasons (Bryant 2009) and, therefore, they may not even perceive ethical issues in the working environment. From a normative perspective, a lack of moral awareness is likely to increase the risk of a person behaving immorally and an increase in business ethics misconduct (Bryant 2009). Hence, moral awareness is the backbone to an individual's sense of moral behaviour and ethical decision-making (Wiid et al. 2013). A summary of the ethical dilemmas and challenges of SMEs in indicated in Table 2:

\section{Methodology}

In this article, the background literature review on ethical practices in SMEs in the context of developing countries has been conducted on several journal articles. Peer-reviewed articles from journals between 2004 and 2016 were analysed. This helped identify the aspects of business ethics, significance of business ethics to SMEs, ethical dilemmas and challenges of SMEs and the proposed strategies to address ethical dilemmas and challenges thereof. The key words used for the literature search are ethics, business ethics, ethical practices and SMEs. 
TABLE 2: Summary of ethical dilemmas and challenges of small and mediumsized enterprises.

\begin{tabular}{ll}
\hline Ethical dilemmas and challenges & Sources \\
\hline $\begin{array}{l}\text { Providing benefits to someone in business or } \\
\text { government to obtain an inappropriate market, } \\
\text { workplace or economic advantage. }\end{array}$ & Abiodun \& Oyeniyi 2014 \\
$\begin{array}{l}\text { Corruption, bribery and fraud. } \\
\text { Piracy and counterfeiting practices. }\end{array}$ & $\begin{array}{l}\text { Rune 2011; Unruh \& } \\
\text { Arreola 2009 }\end{array}$ \\
$\begin{array}{ll}\text { Seeking unethical schemes to access low-quality } \\
\text { Rune 2011 }\end{array}$ \\
$\begin{array}{l}\text { Poods at lower prices and evading taxation. } \\
\begin{array}{l}\text { Padding expense accounts, seeking reimbursement } \\
\text { for questionable or non-existent business expenses, } \\
\text { taking business property or materials for personal use, } \\
\text { soliciting or offering kickbacks and price fixing. }\end{array}\end{array}$ & $\begin{array}{l}\text { Mahmood 2008; Tarus \& } \\
\text { Nganga 2013 }\end{array}$ \\
$\begin{array}{l}\text { Bribery, coercion or bullying, theft, discrimination, fraud, } \\
\text { harassment, dishonesty, cover-ups and pornography. }\end{array}$ & Botha 2012 \\
$\begin{array}{l}\text { Abuse of a company's resources, abusive behaviour } \\
\text { towards employees, lying to employees, Internet abuse, } \\
\text { conflict of interest, discrimination, lying to stakeholders, } \\
\text { employee benefit abuse, employee privacy violation and } \\
\text { falsifying expenses. }\end{array}$ & Collins 2012 \\
\hline
\end{tabular}

\section{Proposed strategies to address ethical dilemmas and challenges}

Dealing with ethical issues requires the input of all stakeholders, a multidisciplinary and multidimensional approach. Therefore, consideration of employability skills such as honesty, ability to work cooperatively, respect for others, pridein one's work, willingness tolearn, dependability, responsibility for one's actions, integrity and loyalty is very critical (Abiodun \& Oyeniyi 2014). It has been noted that ethics is based on a set of moral and ethical values. Such values must be taken seriously to override any human rationalisation, weakness, ego, or personal faults (Putnam 2016). These values include honesty, integrity, responsibility, quality, trust, respect, teamwork and leadership. Good ethics should be most noticeable at the top, and every employee must be accountable to the same rules. Therefore, everyone's common goal should be to build a strong, profitable business that will last. Training must be provided to get everyone on the same page (Putnam 2016). The training should focus on business ethics and how SMEs can introduce the concept in their structure. Hence, SME owners and their employees need to become more educated and more aware of the need for ethics in business. They need to understand what ethics means and how to apply the stakeholder model in making ethical decisions (Donovan 2013).

Business ethics and corporate social responsibility are very important to the success of SMEs (The Institute of Business Ethics 2007). There is the need for SMEs to maintain good, trusting relationships with key stakeholders such as customers, employees, suppliers and the community. It is recommended that SME owners should design a code of ethics as a key tool for implementing business ethics in their businesses. Such code of ethics should translate core values into specific commitments and expected behaviour in relation to the organisation's stakeholders. The code of ethics should also clearly show how the business will address environmental responsibility and how the firm will relate to competitors (Fatoki \& Chiliya 2012). Business ethics should be introduced as a major module in the universities and in institutions of higher learning in developing countries to educate likely entrepreneurs about the importance of ethics.

SMEs need to collaborate with each other and the best way to do this is to form strategic alliances. This will help them to learn about challenges and best practices. Working through associations will also help in promoting fair business practices. Additionally, SMEs should be provided orientation towards developing a long-term vision as opposed to shortterm objectives and how these two are interlinked for business growth as well as benefit of the community (Mahmood 2008).

SME owners practise good faith as the foundation of business engagement with stakeholders. This requires a business to act honestly, and sincerely endeavor to behave in accordance with one's own agreements, ethical standards in the industry and the law itself (Emerson 2009). SME owners must desist from taking unfair advantage of their employees, customers, and other stakeholders. Hence, SMEs must appreciate that doing business requires exercising good faith and honouring their promises and carrying out their responsibilities towards customers and stakeholders with goodwill and good intention. With regard to contracts and other agreements, SME owners must accurately represent their products and services, be honest in transactions and honour their promises.

\section{Conclusion}

Business enterprises can no longer afford to disregard business ethics. There are continuous business failures as a result of unethical practices especially those associated with employees and top executives. This in turn has adversely affected SMEs' reputations and survival, particularly in developing countries. Business organisations and managers need to behave ethically and protect their own business interests if they are to remain competitive. SME owners and their employees need to become more educated and more aware of the need for ethics in business. They need to understand what ethics means and design a code of ethics as a key tool for implementing business ethics in their businesses. Such a code of ethics should translate core values into specific commitments and expected behaviour in relation to the organisation's stakeholders. This article has added to the body of existing literature on ethical practices of SMEs in developing countries. As such, SME owners and managers, as well as the industry, can use the findings of this article to design ethical policy frameworks and guidelines to improve their reputations and competitiveness.

\section{Limitations of the article and directions for future research}

This article mainly focused on the literature review of business ethical practices of SMEs particularly in developing countries. As such, it does not give the current state of ethical practices of SMEs and large companies. Hence, future scholars and researchers should conduct empirical qualitative and quantitative studies covering both SMEs and large companies globally with regard to ethical business practices 
and dilemmas. This will inform the scholars and practitioners on the extent of ethical practices by SMEs and large companies globally, and the challenges encountered.

\section{Acknowledgements Competing interests}

The author declares that he has no financial or personal relationships that may have inappropriately influenced him in writing this article.

\section{References}

Abiodun, A.J. \& Oyeniyi, O.J., 2014, 'Ethical dilemmas in management: An African perspective', Journal of Business Systems, Governance and Ethics 6(2), 36-44. https://doi.org/10.15209/jbsge.v6i2.203

Ahmad, N.H., 2009, 'Doing well by doing good. A study of ethical and socially responsible practices among entrepreneurial ventures in an emerging economy', Frontiers of Entrepreneurship Research 29(12), 1-15.

Ahmad, N.H., Amran, A. \& Halim, H.A., 2012, 'Ethical and socially responsible practices among SME owner-managers: Proposing a multi-ethnic assessment', Journal of Southeast Asian Research 43(2), 1-11. https://doi.org/10.5171/2012.258185

Borade, G., 2012, Difference between ethics and morality, viewed 17 December 2012 from http://www.buzzle.com/articles/difference-between-ethics-and-morality.htm

Botha, H.J., 2012, Investigating the ethical considerations faced by small business entrepreneurs in the informal sector: Zandspruit Township, Johannesburg, viewed 05 June 2012, from http://www.uj.ac.za/EN/Faculties/management/departments/ CSBD/Documents $/ 2010 \% 20$ CSBD \%20Conference $\% 20$ Docs/BS_Botha.pdf

Branko, M., Drago, C. \& Zoran, S., 2015, 'Role of business ethics in management of human resources', Januar-mart 61(1), 85-96.

Bryant, P., 2009, 'Self-regulation and moral awareness among entrepreneurs', Journal of Business Venturing 24(5), 505-518.

Bucholz, R.A., 2003, Fundamental concepts and problems in business ethics, PrenticeHall, Englewood Cliffs, NJ.

Business Ethics Briefing, 2010, Institute of business ethics, London, Charity no: 1084014, issue 6, viewed 06 January 2010, from http://www.ibe.org.uk.

Chun, J.S., Shin, Y., Choi, J.N. \& Kim, M.S., 2011, 'How does corporate ethics contribute to firm financial performance? The mediating role of collective organizational commitment and organizational citizenship behavior', Journal of Management 39(4), 853-877.

Collins, D., 2012, Business ethics: how to design and manage ethical organisations, Wiley, Hoboken, NJ.

Donovan, A.M., 2013, 'The importance of business ethics to small ventures', Entrepreneurship and Innovation Management Journal 1(1), 50-59.

Elbert, R.J. \& Griffin, R.W., 2003, Business essentials, 4th edn., Prentice Hall, Upper Saddle River, NJ.

Emerson, R.W., 2009, Barron's Business Law, Barron's Educational Series, Inc. Hauppauge, NY.

Fatoki, O. \& Chiliya, W., 2012, 'An investigation into the attitudes toward business ethics and corporate social responsibility by local and immigrant SME owners in South Africa', Journal of Social Sciences 32(1), 13-21. https://doi.org/10.1080/09 718923.2012.11893048

Ferrell, O.C., 2004, 'Business ethics and customer satisfaction', Academy of Management Executive 18(2), 126-129. https://doi.org/10.5465/AME.2004.13836176

Goll, I. \& Rasheed, A.A., 2004, 'The moderating effect of environmental munificence and dynamism on the relationship between discretionary social responsibility and firm performance', Journal of Business Ethics 49, 41-54. https://doi.org/10.1023/ B:BUSI.0000013862.14941.4e

Hasnah, H., Ishak, I. \& Sobei, O., 2015, 'Ethics, corporate social responsibility and the use of advisory services provided by SME: Lessons learnt from Japan', Asian Academy of Management Journal 20(1), 71-100

Hatega, G., 2007, 'SME development in Uganda. Private Sector Foundation Uganda', paper presented at a Local SMEs Conference, Sheraton Kampala, 14 March.

Hellriegel, D., Jackson, S.E., Slocum, J., Staude, G., Amos, T., Klopper, H.B. et al., 2008, Management, 3rd South African edn., Oxford University Press, Cape Town.

Hodgelts, R.M. \& Luthans, F., 2003, International management: Culture, strategy and behaviour, McGraw Hill Company Inc., New York.

Hopkins, M., 2005, 'Measurement of corporate social responsibility', International Journal of Management and Decision Making 6(4), 213-231. https://doi. org/10.1504/IJMDM.2005.006549

Jones, J., 2000, 'Ethics revisited. The 1990s: An "ethical decade" or a decade of hypocrisy?', School of Commerce Research Paper, Flinders University, Australia.
Kalyar, M.N., Rafi, N. \& Kalyar, A.N., 2013, 'Factors affecting corporate social responsibility: An empirical study', Systems Research and Behavioral Sciences responsibility: An empirical study, Systems Rese
30(4), 495. https://doi.org/10.1002/sres.2134

Kamunge, M.S, Njeru, A. \& Tirimba, O.I., 2014, 'Factors affecting the performance of small and macro enterprises in Limuru town market of Kiambu County', International Journal of Scientific and Research Publications 4(12), 1-20.

Khomba, J.K. \& Vermaak, F.N.S., 2012, 'Business ethics and corporate governance: An African socio-cultural framework', African Journal of Business Management 6(9), 3510-3518.

Krebs, D.L., 2011, The origins of morality: An evolutionary account, Oxford University Press, New York, NY.

Mahmood, S., 2008, Corporate governance and business ethics for SMEs in developing countries: Challenges and way forward, viewed 20 May 2011, from http://www. kantakji.com/figh/files/companies/w111.pdf

McMurrian, R.C. \& Matulich, E., 2006, 'Building customer value and profitability with business ethics', Journal of Business \& Economics Research 4(11), 11-18.

Medlin, B. \& Green, K.W., 2003, 'Ethics in small business: Attitudes and perceptions of owners/managers', Academy of Entrepreneurship Journal 9(2), 113-132.

Mujtaba, B., 2005, Understanding ethics and morality in business, viewed 22 Apri 2005, from http://www.sbnonline.com/2005/04/understanding-ethics-andmorality-in-business-there-are-distinctdifferences- between-ethics-and-morality/

Mwarari, M.M. \& Ngugi, P.K., 2013, 'Factors influencing listing of Kenyan SMEs in the securities market for capital raising opportunities', European Journal of Management Sciences and Economics 1(2), 99-115.

Naidoo, N., Perumal, S. \& Moodley, S., 2009, 'Ethical dilemmas in business practices of small and medium enterprises in South Africa', Alternation 16(1), 77-98.

Okafor, G.O., 2011, 'The ethical behaviour of Nigerian business students (A study of undergraduate students in business schools)', Arabian Journal of Business and Management Review 1(3), 33-44.

Ononogbo, M.C., Joel, A. \& Edeja, S.M.E., 2016, 'Effect of ethical practices on the corporate image of SMEs in Nigeria: A survey of selected firms in Imo State', International Journal for Research in Business, Management and Accounting 2(8), Internatior $35-45$.

Peppers, D. \& Rogers, M., 2004, Managing customer relationships: A strategic framework, Wiley, Hoboken, NJ.

Putnam, M.S., 2016, Ethical values for business success, Global Ethics University, Bothel, WA.

Riley, J., 2012, Introduction to business ethics, viewed 18 February 2013, from http:// www.tutor2u.net/business/strategy/business-ethics-introduction.html

Rossouw, R., 2004, Business ethics, 3rd edn., Oxford University Press, Cape Town.

Rune, A., 2011, Corruption and SMEs: Exploring the business case for western SMEs to counter involvement in administrative corruption in developing countries, Master's thesis. Copenhagen Business School, Business and Development Studies, Frederiksberg, Denmark.

Spence, E. \& Van Heekeren, B., 2005, Advertising ethics, Pearson Education, Inc., Upper Saddle River, NJ.

Sraboni, D. \& Sharmistha, B., 2011, 'Ethical practices towards employees in smal enterprises: A quantitative index', International Journal of Business Management and Economic Research 2(3), 205-221.

Tarus, D.K. \& Nganga, S.I., 2013, 'Small and medium size manufacturing enterprises growth and work ethics in Kenya', Developing Country Studies 3(2), 51-59.

The Institute of Business Ethics, 2007, Small enterprises, big change - How mentoring makes a difference, viewed 10 September 2011, from https://www.saica.co.za/ tabid/695/itemid/2324/Small-enterprises-Big-Changes-How-Mentoring-Mak. aspx

Twomey, D.P. \& Jennings, M.M., 2011, Anderson's business law and the legal environment, 21st edn., South-Western Cengage Learning, Mason, $\mathrm{OH}$.

Uganda Ministry of Finance, Planning and Economic Development, 2011, The national micro, small and medium enterprise (MSME) policy draft report, MOFPED, Kampala, Uganda.

Unruh, G. \& Arreola, F., 2009, Global compliance: Nigeria, viewed 12 March 2010, from http://ethispher.com/global-compliance-nigeria

Velentzas, J. \& Broni, G., 2010, 'Ethical dimensions in the conduct of business: Business ethics, corporate social responsibility and the law. The "ethics in business" as a sense of business ethics', Paper presented at the International Conference on Applied Economics (ICOAE), Athens, 26-28 August.

Webley, S. \& More, E., 2013, Does business ethics pay? Ethics and financial performance, Institute of Business Ethics, London.

Weinstein, A., 2012, Superior customer value: Strategies for winning and retaining customers, 3rd edn., CRC Press, Coral Springs, FL.

Werner, A. \& Spence, L.J., 2004, 'Literature review: Social capital and SMEs', in L.J. Spence, A. Habisch \& R. Schimidpeter (eds.), Responsibility and social capital: The world of small and medium sized enterprises, pp. 7-24, Palgrave MacMillan, New York, NY

Wiid, J.K., Cant, M.C. \& Van Niekerk, C., 2013, 'Moral behaviour and ethical misconduct in Nigerian small businesses', International Business \& Economics Research Journal 12(9), 1087-1100. https://doi.org/10.19030/iber.v12i9.8054 